Journal of Food and Nutritional Sciences Research (JFNSR)

Volume 2, Issue 2, Pages $100-111$

Received 06-09-2020, Reviewed 23-11-2020, Accepted 30-11-2020

https://doi.org/10.37512/900

\title{
COPING STRATEGIES TO FOOD INSECURITY EMPLOYED BY STUDENTS OF KARATINA UNIVERSITY, KENYA.
}

\author{
${ }^{1}$ Daniel, S. Sewe, ${ }^{1 * *}$ Michael N.I. Lokuruka \\ ${ }^{1}$ Department of Food Science and Nutrition, Karatina University, P.O Box, 1957-10101, \\ Karatina, Kenya. \\ E-mails - stephensewe9@ gmail.com; mlokuruka@karu.ac.ke; mlokuruka@ gmail.com. \\ ** corresponding author: Michael N.I. Lokuruka, Ph.D., EBS \\ Department of Food Science and Nutrition, Karatina University, P.O Box, 1957-10101, \\ Karatina, Kenya. E-mail: mlokuruka@gmail.com and mlokuruka@karu.ac.ke
}

\begin{abstract}
It has been reported that 1 in 3 Kenyans suffers from severe food insecurity and poor nutrition. This study aimed to establish the level of food insecurity among Karatina University students and the coping strategies employed. A nutrition survey research design and random sampling was done with a sample size of 94 students, who resided within the university. Proximate composition by AOAC methods and nature of frequently consumed foods was determined. Dietary and non-dietary coping strategies to food insecurity were established. The percentage of students who were food insecure was $27.9 \%$ as evidenced by skipping a meal more than once every week of the month due to lack of enough money. Also, 22.3\% borrowed foods from friends and neighbours, $48.9 \%$ stuck to simple and affordable meals, which were either, rice+beans/green grams or "ugali"+cabbage/ leafy green vegetables or "ugali"+beans/green grams. The non-dietary coping strategies showed $18.1 \%$ students reducing expenditure on airtime, while $2.1 \%$ sold assets-mobile phones and laptops. The most consumed daily meal was "chapatti" + beans/green grams at 26.6 and $27.7 \%$ for male and females, respectively, while the least consumed meal was "ugali" + beans/green grams at 5.3 and $3.2 \%$ for male and female students, respectively. Animal proteins as part of daily meals were hardly consumed due to the high sales price. Both genders met their daily calorie and dietary protein recommendation. The dimension of food security that was not met by students was affordability.
\end{abstract}

KEYWORDS: Coping strategies, Food insecurity, University students, Kenya 


\section{INTRODUCTION}

Food security is defined as a state of having reliable access to sufficient quantity of affordable and nutritious food (FAO, 2015). Despite the right of every person to be free from effects of food insecurity as was declared during the World Food Conference of 1974 (GOK, 2008a), the effects linger in the global society. While it is well documented that food insecurity impacts many children and families, there is limited research on prevalence and impact of food insecurity among university students. In Kenya, 10 million persons and their households are highly food insecure (Kenya Food Security Steering Group, 2008). Families may qualify for relief food programme from government or non-governmental organizations to help them become food secure. However, university students have not been included in food assistance programmes. This leaves a large percentage of young adults aged 18-25 ineligible for food aid assistance in a stage of life where finances are limited (SNAP, 2016). Kenya looks towards achieving the Sustainable Development Goals. The first goal is "alleviation of extreme poverty and hunger", which the country plans to achieve by reducing the proportion of people who suffer from hunger by half (GOK, 2008). To achieve this, implementing the SDG's plans at the grass root levels is imperative. This could ensure reduction of food insecurity. Food insecurity at higher learning institutions is not a new phenomenon, but it is not openly addressed, especially at an institutional leadership level (Scholey et al., 2001). A key question is how the universities in collaboration with other relevant stakeholders can engage in finding common workable interventions on food insecurity at institutions of higher learning (IHL) (Munro, 2013). There should be some emphasis on the distribution of resources to populations that are vulnerable such as the student population at IHLs, so as to alleviate food insecurity. Food security studies at Universities have used different methods of measuring and analyzing food insecurity. Estimates of food insecurity among university students ranged from $11 \%$ to $38.3 \%$ in South Africa (Munro, 2013), $12.7 \%$ to 46.5\% in Australia (Masutha, 2011), 21\% in Hawaii (Crush and Frayne, 2010) and 39.2\% in New York, USA (Freudenberg and Middleton, 2001). Karatina University, where this study was done, is a Chartered Public University in Kenya, and is situated $15 \mathrm{~km}$ North of Karatina town in Nyeri County, Kenya. The University has six Academic Schools and has Campuses in Kagochi (Main), the School of Business at Karatina town and School of Education and Social Sciences at Itiati. The research methods used by the above other studies included considering the relationship between food insecurity and item expenditures and the use of trained students to do the interviews and gather data, among other methods. Our study assessed the coping strategies by the students when they are unable to acquire food and establish the dimension of food security that the students do not meet. We used questionnaires administered randomly to students by the first author and filled by the respondents. Samples of commonly consumed foods for food composition studies were bought at the University cafeteria as students would normally buy. The detailed methods are further described in the appropriate sections below.

The objectives of the study were:

1. To establish coping strategies to food insecurity employed by Karatina university students

2. To establish foods commonly consumed by students of Karatina University

3. To estimate the typical daily energy intake by a student

4. To determine the dimension of food security that is not met by food insecure students 


\section{METHODS AND PROCEDURES}

A nutrition survey research design, random sampling and quantitative nutrient analysis was used to determine the dietary and non -dietary coping strategies to food insecurity and diets consumed by students when they are both food secure and insecure. The nutrient analysis determined the nutrients: carbohydrates, proteins and lipids in some frequently consumed foods in order to be able to calculate the daily energy intake from a daily food plan for both female and male students.

Questionnaires were administered to the sample of the student population residing in the main campus hostels. Students were randomly picked to participate in the study after signing an informed consent.

The total student population consisted of over 6700 students from diverse cultures and socioeconomic backgrounds, but mainly from Kenya. Of these, over 1500 resided in the campus hostels. Students who reside within the university buy their food mainly from the University cafeteria, which offers meals at subsidized prices. The meals can be purchased using meal cards administered by the university catering department or payment in cash on service.

\section{Sample size determination}

The sample size comprised of 94 students ( 47 male and 47 female students). The sample size was calculated using the amended Yamane formula (Project Crew, 2015). The total number of students residing in the main campus is approximately 1500 students. $\mathrm{n}=\mathrm{N} \div 1+\mathrm{N}(\mathrm{e})^{2}$. Where $\mathrm{n}$ is the corrected sample size, $\mathrm{N}$ is the population size and $\mathrm{e}$ is the precision rate. $\mathrm{n}=$ $1500 / 1+1500(0.1)^{2}=94$ respondents ( 47 male +47 female). The food samples were purchased at the university cafeteria and then measured using a $250 \mathrm{ml}$ standard cup to ascertain the volume of liquid foods. A digital weighing scale calibrated to the zero mark was used to weigh the solid foods.

\section{Proximate Analysis of Composite Common Foods}

Protein, fat (using Soxhlet's extraction method) and carbohydrate composition (using Anthrone method) were determined as described in AOAC (2005).

\section{Protein}

This was determined by the method in AOAC (2017), a procedure that is based on the Kjeldahl Method.

\section{Determination of fat content}

Fat content of the foods analyzed was determined by the amended Soxhlet extraction method 920.85 (Hawachi Scientific, 2018), using a 5-g sample and petroleum ether (B.P. $40-60^{\circ} \mathrm{C}$ ) as the solvent. The amount of fat extracted was calculated as follows.

$$
\text { Fat } \%=\frac{\text { weight of fat extracted }}{\text { weight of sample }} \times 100
$$

\section{Determination of carbohydrates}

Carbohydrates are first hydrolyzed into simple sugars using dilute hydrochloric acid. In hot acidic medium glucose is dehydrated to hydroxymethyl furfural. The compound forms a green 
colored product with anthrone and its amount was determined at an absorption wavelength of $630 \mathrm{~nm}$ using an Atomic Absorption spectrophotometer (Devindra, 2015).

\section{RESULTS AND DISCUSSION}

Table 1 illustrates the strategies used by students to cope with food insecurity. The most used way of adjusting to food insecurity was sticking to simple and affordable meals such as "ugali" + cabbage/kale/spinach, or "chapatti" + beans stew, or rice + beans stew and rice+ cabbage/kales/spinach. Others are illustrated in Table 1.

\section{Table 1: Students' Coping Strategies to Food Insecurity}

\begin{tabular}{|l|l|}
\hline Coping strategies & Number of students (\%) \\
\hline Borrowed food from friends & 22.3 \\
\hline $\begin{array}{l}\text { Stuck to simple and affordable } \\
\text { food items }\end{array}$ & 48.9 \\
\hline $\begin{array}{l}\text { Reduced expenditure on } \\
\text { airtime }\end{array}$ & 18.1 \\
\hline Skipped a meal in a day & 8.5 \\
\hline $\begin{array}{l}\text { Used all of the above } \\
\text { strategies over different } \\
\text { periods in a month }\end{array}$ & 2.2 \\
\hline
\end{tabular}

Note: Note that gender was not taken into account in the above computations.

Table 2 shows the meals and quantity consumed based on gender. The most consumed daily meal was "chapatti" + beans/green grams at 26.6 and $27.7 \%$ for male and female students, respectively. "Chapatti" is normally a hard-to-get food as wheat flour tends to be expensive to buy and the process of making it is tedious and it tends to be expensive.to buy. So when it is sold cheaply at the University cafeteria, students take advantage of its availability.

It is high in fat because liberal amounts of oil or fat is used to make them, unlike the Indian Nan. As it is cooked with liberal amounts of fat/oil, it is a satiety and fullness inducing food. Fat gives flavor to foods and the considerable amount of fat in the chapatti makes it a favorite Kenyan food generally. The least consumed meal was "ugali" + beans/green grams at $5.3 \%$ and $3.2 \%$ by male and female students, respectively. "Ugali" is the favourite Kenyan staple cereal food and it is cheap. It is a food that makes one feel satiated for long. So a student wishing to get full and remain satiated for a good part of the day running from one lecture to another would preferably buy a meal with "Ugali" as part of it. Meals consisting of red meat were hardly consumed due to the cost and also its low availability in the cafeteria. It is rarely cooked as the sales can be low in a situation where students try to keep expenditure on food as low as possible. The least consumed food commodity by both genders was an animal protein source. Animal protein foods were not consumed daily due to the high cost of the commodities. However, female students consumed more milk and dairy products as well as fruits than male students. Hence they would potentially be healthier than the male students-their diets would probably contain higher protein content with a good supply of the essential amino acids and minerals including calcium from animal foods such as eggs and dairy products.

Most students also consumed considerable amount of plant foods, which are low in saturated fatty acids, but high in fibre and phytates (these included beans, green grams, and green leafy 
vegetables)-these are generally regarded as healthy foods. Cooking probably reduced the potential of phytates and fibrous food components to bind dietary minerals and therefore the bioavailability of dietary minerals would not be affected much (Castillo, 2007), despite the students consuming predominantly plant-based diets.

Table 2: Common daily meal combinations

\begin{tabular}{|c|c|c|c|c|c|c|c|c|}
\hline \multirow[t]{2}{*}{ Food } & \multirow[t]{2}{*}{ Quantity } & \multicolumn{3}{|c|}{ \% Male } & \multirow[t]{2}{*}{ Quantity } & \multicolumn{3}{|c|}{$\%$ Female } \\
\hline & & $\begin{array}{l}\text { Breakfa } \\
\text { st }\end{array}$ & $\begin{array}{l}\text { Lunc } \\
\text { h }\end{array}$ & $\begin{array}{l}\text { Dinne } \\
\mathbf{r}\end{array}$ & & $\begin{array}{l}\text { Breakfa } \\
\text { st }\end{array}$ & $\begin{array}{l}\text { Lunc } \\
\mathrm{h}\end{array}$ & $\begin{array}{l}\text { Dinne } \\
\mathbf{r}\end{array}$ \\
\hline $\begin{array}{l}{ }^{1} \text { Chapatti + } \\
\text { sweet tea } \\
\text { (beverage) }\end{array}$ & $\begin{array}{l}2 \text { pieces } \\
(74.2 \mathrm{~g} \\
\text { each })+1 \\
\operatorname{cup}(250 \\
\mathrm{mL})\end{array}$ & 26.6 & ---- & --- & $\begin{array}{l}2 \text { pieces } \\
(74.2 \mathrm{~g} \\
\text { each })+1 \\
\operatorname{cup}(250 \\
\mathrm{mL})\end{array}$ & 31.9 & --- & --- \\
\hline $\begin{array}{l}{ }^{1} \text { Mandazis + } \\
\text { sweet tea } \\
\text { (beverage) }\end{array}$ & $\begin{array}{l}4 \text { pieces } \\
(41.1 \mathrm{~g} \\
\text { each })+1 \\
\text { cup }\end{array}$ & 73.4 & --- & --- & $\begin{array}{l}4 \text { pieces } \\
(41.1 \mathrm{~g} \\
\text { each })+1 \\
\text { cup }\end{array}$ & 68.1 & --- & --- \\
\hline $\begin{array}{l}{ }^{1} \text { Chapatti + } \\
\text { beans/green } \\
\text { grams in } \\
\text { broth }\end{array}$ & $\begin{array}{l}(74.2 \mathrm{~g} \\
\text { each for } \\
\text { chapatti } \\
\text { and } 125 \mathrm{~g} \\
\text { for green } \\
\text { grams/bean } \\
\text { s) }\end{array}$ & --- & 24.5 & 26.6 & $\begin{array}{l}(74.2 \mathrm{~g} \\
\text { each for } \\
\text { chapatti } \\
\text { and } 125 \mathrm{~g} \\
\text { for green } \\
\text { grams/bean } \\
\mathrm{s})\end{array}$ & --- & 24.5 & 27.7 \\
\hline $\begin{array}{l}{ }^{2} \text { Chapatti + } \\
\text { red meat in } \\
\text { broth }\end{array}$ & $\begin{array}{l}\text { (74.2 } \mathrm{g} \text { for } \\
\text { each } \\
\text { chapatti } \\
\text { and } 50 \mathrm{~g} \\
\text { for meat) }\end{array}$ & --- & 3.2 & 3.2 & $\begin{array}{l}\text { ( } 74.2 \mathrm{~g} \text { for } \\
\text { each } \\
\text { chapatti } \\
\text { and } 50 \mathrm{~g} \\
\text { for meat) }\end{array}$ & --- & 6.4 & 3.2 \\
\hline $\begin{array}{l}{ }^{2} \text { Ugali }+ \\
\text { cabbage/kale } \\
\text { s } \\
\text { In broth }\end{array}$ & $\begin{array}{l}(203.4 \mathrm{~g} \\
\text { for ugali } \\
\text { and } 125 \mathrm{~g} \\
\text { for cabbage } \\
/ \mathrm{kale})\end{array}$ & --- & 10.6 & 19.1 & $\begin{array}{l}(203.4 \mathrm{~g} \\
\text { for ugali } \\
\text { and } 125 \mathrm{~g} \\
\text { for cabbage } \\
\text { /kale })\end{array}$ & --- & 5.3 & 7.4 \\
\hline $\begin{array}{l}{ }^{2} \text { Ugali + red } \\
\text { meat in } \\
\text { broth } \\
+ \text { cabbage/ka } \\
\text { le }\end{array}$ & $\begin{array}{l}\text { (203.4g for } \\
\text { ugali, } 50 \mathrm{~g} \\
\text { for meat) } \\
\text { and } 125 \mathrm{~g} \\
\text { for cabbage } \\
\text { /kale) }\end{array}$ & --- & 6.4 & 4.3 & $\begin{array}{l}(203.4 \mathrm{~g} \\
\text { for ugali, } \\
50 \mathrm{~g} \text { for } \\
\text { meat) and } \\
125 \mathrm{~g} \text { for } \\
\text { cabbage } \\
/ \text { kale) }\end{array}$ & --- & 10.6 & 6.4 \\
\hline $\begin{array}{l}{ }^{2} \text { Ugali + red } \\
\text { meat in } \\
\text { broth }\end{array}$ & $\begin{array}{l}\text { (203.4 } \mathrm{g} \text { for } \\
\text { ugali and } \\
50 \mathrm{~g} \text { for }\end{array}$ & --- & 8.5 & 3.2 & $\begin{array}{l}\text { (203.4 } \mathrm{g} \text { for } \\
\text { ugali and } \\
50 \mathrm{~g} \text { for }\end{array}$ & --- & 9.6 & 10.6 \\
\hline
\end{tabular}




\begin{tabular}{|c|c|c|c|c|c|c|c|c|}
\hline & meat) & & & & meat) & & & \\
\hline $\begin{array}{l}{ }^{2} \text { Ugali }+ \\
\text { beans/green } \\
\text { grams in } \\
\text { broth }\end{array}$ & $\begin{array}{l}\text { (203.4 g for } \\
\text { ugali and } \\
125 \mathrm{~g} \text { for } \\
\text { green } \\
\text { grams/bean } \\
\mathrm{s})\end{array}$ & --- & 5.3 & 10.6 & $\begin{array}{l}\text { (203.4 g for } \\
\text { ugali and } \\
125 \mathrm{~g} \text { for } \\
\text { green } \\
\text { grams/bean } \\
\mathrm{s})\end{array}$ & --- & 3.2 & 2.1 \\
\hline $\begin{array}{l}{ }^{2} \text { Rice }+ \text { red } \\
\text { meat in } \\
\text { broth+ } \\
\text { cabbage/kale }\end{array}$ & $\begin{array}{l}\text { (257 } \mathrm{g} \text { for } \\
\text { rice, } 50 \mathrm{~g} \\
\text { for meat } \\
\text { and } 125 \mathrm{~g} \\
\text { for cabbage } \\
/ \mathrm{kale})\end{array}$ & --- & 5.3 & 2.1 & $\begin{array}{l}\text { (257 } \mathrm{g} \text { for } \\
\text { rice, } 50 \mathrm{~g} \\
\text { for meat } \\
\text { and } 125 \mathrm{~g} \\
\text { for cabbage } \\
\text { /kale) }\end{array}$ & --- & 5.3 & 4.3 \\
\hline $\begin{array}{l}{ }^{2} \text { Rice }+ \text { red } \\
\text { meat in } \\
\text { broth }\end{array}$ & $\begin{array}{l}\text { (257 } \mathrm{g} \text { for } \\
\text { rice and } 50 \\
\mathrm{~g} \text { for meat) }\end{array}$ & --- & 8.5 & 1.1 & $\begin{array}{l}\text { (257 } \mathrm{g} \text { for } \\
\text { rice and } 50 \\
\mathrm{~g} \text { for meat) }\end{array}$ & --- & 9.6 & 3.2 \\
\hline $\begin{array}{l}{ }^{2} \text { Rice + } \\
\text { beans/green } \\
\text { grams + } \\
\text { cabbage/kale }\end{array}$ & $\begin{array}{l}\text { (257 } \mathrm{g} \text { for } \\
\text { rice, } 125 \mathrm{~g} \\
\text { for green } \\
\text { grams/bean } \\
\mathrm{s} \text { and } 125 \mathrm{~g} \\
\text { for cabbage } \\
\text { /kale) ) }\end{array}$ & --- & 12.8 & 12.8 & $\begin{array}{l}\text { (257 } \mathrm{g} \text { for } \\
\text { rice, } 125 \mathrm{~g} \\
\text { for green } \\
\text { grams/bean } \\
\mathrm{s} \text { and } 125 \mathrm{~g} \\
\text { for cabbage } \\
\text { /kale) ) }\end{array}$ & --- & 10.6 & 21.3 \\
\hline $\begin{array}{l}{ }^{2} \text { Rice }+ \\
\text { beans/green } \\
\text { grams }\end{array}$ & $\begin{array}{l}(257 \mathrm{~g} \text { for } \\
\text { rice and } \\
125 \mathrm{~g} \text { for } \\
\text { green } \\
\text { grams/bean } \\
\mathrm{s}\end{array}$ & --- & 14.9 & 17.0 & $\begin{array}{l}(257 \mathrm{~g} \text { for } \\
\text { rice and } \\
125 \mathrm{~g} \text { for } \\
\text { green } \\
\text { grams/bean } \\
\mathrm{s}\end{array}$ & --- & 14.9 & 13.8 \\
\hline
\end{tabular}

Legend: 'Breakfast meal; ${ }^{1}$ Lunch and dinner meal; "Chapatti": a pan-baked flat bread; "Ugali": a stiff cooked maize meal; Mandazi: a deep-fried bread from self-raising flour (deep-brown in colour).

Table 3 shows the meals by food group skipped by students in an effort to minimize expenditure on food.

Table 3: Percentage of students who skipped certain food groups in a day

\begin{tabular}{|l|l|l|}
\hline Type of food & $\begin{array}{l}\text { Number of students }(\%), \\
\text { male }\end{array}$ & $\begin{array}{l}\text { Number of students } \\
(\%), \text { female }\end{array}$ \\
\hline $\begin{array}{l}\text { Carbohydrates i.e. (ugali, } \\
\text { chapatti and rice }\end{array}$ & 3.2 & 13.9 \\
\hline Animal Proteins & 52.1 & 47.9 \\
\hline $\begin{array}{l}\text { Plant Proteins (legumes } \\
\text { i.e. kidney beans) }\end{array}$ & 13.8 & 10.6 \\
\hline Vegetables (cooked) & 6.4 & 13.8 \\
\hline Fruits & 8.5 & 5.3 \\
\hline
\end{tabular}


Milk and Dairy products

16.0

8.5

N.B: Oils/fats are consumed through fried and cooked foods (so it is not included in the table as a food group).

Table 3 above shows the percentage of students who skipped various food groups in a day as a way of coping with the lack of adequate money for the purchase of food. Animal protein was the most skipped food, especially by the male students. The percentage that skipped taking animal proteins in a day was $52.1 \%$ and $47.9 \%$ for male and female students, respectively (Table 3 ). The quality of the protein available from the plant-based meals may therefore be low for young growing persons of University age group (18-25 years).

The most consumed daily meal was "chapatti" + beans/green grams at 26.6 and $27.7 \%$ for male and female students, respectively. The least consumed meal was "ugali" + beans/green grams at $5.3 \%$ and $3.2 \%$ for male and female students, respectively. Meals consisting of red meat were hardly consumed due to the high sales price. The least consumed food commodity by both genders was animal protein as indicated by the high skipping of flesh in common daily meals (Table 3). This led to its exclusion from the meal plans by both genders (Table 5).

\section{Daily Energy intake}

1 gram of protein and carbohydrate each provide 4 kilocalories ( $\mathrm{K}$ cal), while 1 gramme of fat provides $9 \mathrm{~K}$ cal (WHO, 2018). It should also be noted that the National Academy of Sciences (NAS, 2020) recommends 1900-2200 K cal/day for active females and 2300-2900 K cal/day for active males. The indicative energy intakes for the two genders are thus compared and discussed below.

\section{Breakfast meals and energy intake}

For male students-going by a typical daily student meal, male students who consumed "chapatti" and tea as breakfast as shown in Table 5, consumed a total of $573.28 \mathrm{~K}$ cal at breakfast. Male students who consumed 4 "mandazi" and tea at breakfast consumed a total of $613.6 \mathrm{~K}$ cal.

For Females-Female students who consumed 3 "mandazi", one boiled egg and tea as breakfast consumed for a total of $573.6 \mathrm{~K}$ cal during breakfast. When they consumed "chapatti", one boiled egg and tea for breakfast as shown in Table 5, the energy intake is $620.2 \mathrm{~K}$ cal.

Lunch and dinner for both genders-for the lunch meal, both male and female students often took the same meal (2 "chapatti" $+125 \mathrm{~g}$ of green grams or beans as shown in Table 5 . They consumed a total of $1077.6 \mathrm{~K} \mathrm{cal}$ from the lunch meal. Both genders also frequently consumed the same meal for dinner. The calorie intake from dinner, for $257 \mathrm{~g}$ rice $+125 \mathrm{~g}$ of green grams or beans was a total of $975.8 \mathrm{~K}$ cal.

Therefore, female students consumed approximately a total of $2627.04 \mathrm{~K} \mathrm{cal} /$ day while male students consumed a total of $2666.02 \mathrm{k} \mathrm{cal} / \mathrm{day}$. The recommended calorie intake is $1900-2200 \mathrm{k}$ $\mathrm{cal} /$ day for females, while the male daily caloric intake was within the normal range as the recommended intake is $2300-2900 \mathrm{~K} \mathrm{cal} /$ day (NAS, 2020). The over-consumption of calories by female students can lead to weight gain, and is not recommended for a healthy lifestyle. School girls in Kenya have been reported to suffer from overweight and a tendency to obesity than the 
boys (Adamo et al., 2010), though the cohorts in this study were primary school children of age 3-13 years, who may not, however, compare in many respects with the University students in the current study (18-25 years of age). In other studies, Muhihi et al. (2013) found the percentage of obesity/overweight in girls among children in private primary schools in Dar es Salaam, Tanzania, were higher than that of boys (6.3\% for girls and 3.8\% for boys), but again these were younger children than the University students in the current study, who may have better knowledge of the benefits of physical activity and healthy food choices for a healthy body weight. In Cameroon, Choukem et al. (2018) established the overweight /obesity percentage to be $13.2 \%$ for girls compared to $11.9 \%$ for boys of similar age (3-13 years).

The recommended daily allowance for dietary protein is $0.8-1.0 \mathrm{~g} / \mathrm{kg}$ body weight/day for adults, (Daniel, 2015). According to Table 5, male students consumed $67.6 \mathrm{~g}$ of protein/day, whereas female students consumed $78.6 \mathrm{~g}$ of protein/day. The daily percentage of calories from protein should be $10-15 \%$ of total calories (WHO, 2018).

The percentage range of protein that the students should take as calculated using the $10-15 \%$ of total calories recommendation should be $65.7 \mathrm{~g} / \mathrm{day}$ to $98.5 \mathrm{~g} / \mathrm{day}$ and $66.7 \mathrm{~g} / \mathrm{day}$ to $100 \mathrm{~g} / \mathrm{day}$ for female and male students, respectively. Female students frequently added 1 boiled egg to their breakfast meal as compared to male students. This was healthy for them since the highly bioavailable heme iron from the egg aids in obviating the negative effects of iron loss during menstruation. Both student genders met the daily protein recommended allowance as well as the recommended daily calorie intake for their age and occupation.

Table 4-Proximate Composition of Frequently Consumed Foods.

\begin{tabular}{|l|l|l|l|}
\hline SAMPLE & \% PROTEIN $(\mathbf{g} / \mathbf{1 0 0 g})$ & $\begin{array}{l}\text { \% CHO } \\
\text { (g/100g) }\end{array}$ & $\begin{array}{l}\text { \% FAT } \\
(\mathbf{g} / \mathbf{1 0 0 g})\end{array}$ \\
\hline $1-$ rice & 2.38 & 82.14 & 0.3 \\
\hline $\begin{array}{l}2-\text { rice and beans } \\
\text { (composite) }\end{array}$ & 12.47 & 79.76 & 1.2 \\
\hline $\begin{array}{l}3-\text { chapatti and } \\
\text { beans(composite) }\end{array}$ & 8.61 & 85.91 & - \\
\hline
\end{tabular}

Table 5: Typical Student Daily Meal Plan and Expenditure

\begin{tabular}{|c|c|c|c|c|c|c|c|c|}
\hline \multirow[t]{2}{*}{ Meal } & \multicolumn{4}{|c|}{ Male } & \multicolumn{4}{|c|}{ Female } \\
\hline & Breakfast & Lunch & Fruit/snack & $\begin{array}{l}\text { Dinne } \\
\mathbf{r}\end{array}$ & Breakfast & Lunch & Fruits/snack & $\begin{array}{l}\text { Dinne } \\
\mathbf{r}\end{array}$ \\
\hline $\begin{array}{l}\text { Price } \\
(\text { KES) }\end{array}$ & 30 & 40 & 10 & 40 & 40 & 40 & 10 & 30 \\
\hline $\begin{array}{l}\text { Cooked } \\
\text { food } \\
\text { item }\end{array}$ & $\begin{array}{l}\text { Tea } \\
\text { beverage } \\
(250 \mathrm{~mL}) \\
+4 \\
\text { mandazi/ } \\
2 \text { chapatti }\end{array}$ & $\begin{array}{l}2 \\
\text { chapatti } \\
\mathrm{s}(\text { each } \\
74.2 \mathrm{~g}) \\
+125 \mathrm{~g} \\
\text { of green } \\
\text { grams or } \\
\text { beans }\end{array}$ & $\begin{array}{l}1 \text { piece of } \\
\text { mango, } \\
\text { banana or } \\
\text { watermelon } \\
\text { / or } 2 \text { apple } \\
\text { size cakes }\end{array}$ & $\begin{array}{l}257 \mathrm{~g} \\
\text { rice }+ \\
125 \mathrm{~g} \\
\text { of } \\
\text { green } \\
\text { grams } \\
\text { or } \\
\text { beans }\end{array}$ & $\begin{array}{l}\text { Tea } \\
\text { beverage } \\
(250 \mathrm{~mL}) \\
+ \text { one } \\
\text { boiled } \\
\text { egg }+3 \\
\text { mandazi/ } \\
2 \text { chapatti }\end{array}$ & $\begin{array}{l}2 \\
\text { chapatti } \\
\mathrm{s}(\text { each } \\
74.2 \mathrm{~g}) \\
+125 \mathrm{~g} \\
\text { of green } \\
\text { grams or } \\
\text { beans }\end{array}$ & $\begin{array}{l}2 \text { pieces of } \\
\text { mango, } \\
\text { banana or } \\
\text { watermelon/ } \\
2 \text { apple size } \\
\text { cakes }\end{array}$ & $\begin{array}{l}257 \mathrm{~g} \\
\text { rice }+ \\
125 \mathrm{~g} \\
\text { of } \\
\text { green } \\
\text { grams } \\
\text { or } \\
\text { beans }\end{array}$ \\
\hline
\end{tabular}




\begin{tabular}{|l|l|l|l|l|l|l|l|l|}
\hline $\begin{array}{l}\text { Protein } \\
\text { content } \\
\text { g/100 } \\
\text { g food }\end{array}$ & 8.0 & 23.5 & - & 36.1 & 19 & 23.5 & - & 36.1 \\
\hline
\end{tabular}

N.B: Meals in each column are sold at the same price shown at the top row; KES-Kenya Shilling

\section{Dimension of food security not achieved by students}

The dimension of food security that was not achieved by students was affordability. The male student population skipped more meals than the female students. Students rely on the Kenyan Government Higher Education Loans Board (HELB) funding for fees and upkeep. HELB loan disbursements were the same for male and female, ignoring the observation that female students' expenditure patterns necessitate higher allocations (Odebero et al., 2007). Students from the School of Nursing and School of Agriculture and Biotechnology paid more school fees due to the practically-oriented nature of their programmes. These students would therefore potentially be left with a lower amount of money for upkeep and for food for the semester. They would be at a higher risk of not meeting the daily recommended dietary allowances (RDA) for nutrients. However, the survey did not estimate the number of students from the two schools due to the random selection of respondents. Animal protein consumption was low due to the high cost of these food commodities. For example, fried meat + "Ugali" costs KES 60, fried eggs + "Ugali" costs KES 50. Of those who could afford, the percentage that consumed animal protein in a day was $21.3 \%$ males and $26.6 \%$ females, respectively. Of those who consumed animal protein food, beef was the choice, as it was cheaper than chicken. It was consumed at least once a week. At the University of Witwatersrand in South Africa, food security coping strategies used by students included avoiding expensive fast-food places, food pooling, shared meal preparation schedules, eating fewer meals and going home to get food (Rudolph et al., 2018). Similar to the South African students, Karatina University students ate fewer meals as a coping strategy for food insecurity. Students of Karatina University are not permitted to cook in the hostels and therefore feed on readily prepared meals bought from the University Cafeteria and food kiosks close to the halls of residence. At the University of Witwatersrand, the major dimension of food insecurity that was not met was affordability as evidenced by the purchase of cheaper foods, sharing meal preparation and eating fewer meals (Rudolph et al., 2018). This was the same case with Karatina University students who live on cheap foods, skip some meals and avoid animal protein food products such as beef, chicken and eggs for a part of the semester.

More Karatina University male students skipped more meals than female students as they lacked enough money to buy the next meal. Skipping meals has a negative implication for health because the body has inbuilt biological adaptive mechanisms to store nutrients especially the carbohydrates, which are converted to fat and stored in body organs to be used during starvation (Kissler, 2020). The skipping of meals may therefore not be beneficial from a health perspective. Male students on average spent Kenya Shillings 120 (USD 1.20) per day for food, whereas female students on average spent a little more, about Kenya shillings 130 (USD 1.30) (Table 5). Typically, student's expenditure on the 3 meals in a day is about 120 KES (Table 5). Both genders therefore spent about the same amount of money on food, as shown in the typical students' meal plan and expenditure schedule in Table 5. 
Limitations of the study: Due to the short time available for the study, a comprehensive proximate composition of the foods consumed by students was not done. Limited finance also constrained the scope and depth of the study. Self-reporting could also have compromised the results.

\section{CONCLUSIONS}

Female students consumed more diverse foods (including more eggs, milk and dairy products) than male students. Male students consumed lower amounts of animal proteins and fruits than the females. The students lived mainly on plant-based foods. However, both genders met the recommended daily dietary intake of calories and protein.

The most used strategy to stretch the money available, in an effort to try to meet the daily food needs, was borrowing food from friends and neighbours, sticking to simple, low-priced food items and skipping some meals. The major cause of food insecurity among the students was lack of adequate money to buy enough and appropriate daily meals. The dimension of food security not met by students in this study was therefore affordability.

\section{RECOMMENDATIONS}

The study recommends that:

a. The University establishes food/cash-for-work programme for needy students

b. The University Management sets up a support system for food insecure students to enable them acquire adequate and good quality food, which is likely to enhance health, a positive factor for academic success

c. That University Management starts an awareness campaign and offer a range of training programmes to educate and inform students on the negative impacts of hunger and poor nutrition on general health and learning outcomes

d. Further studies be done on income level of students, parents and guardians who support students financially

\section{ACKNOWLEDGEMENT}

We appreciate the students for their cooperation and others for providing the necessary assistance to enable the completion of the survey.

\section{Conduct and Funding of the Study}

Michael Lokuruka provided the funding for the study and advised on the procedures to follow in the course of the study. Daniel Sewe developed the questionnaire and conducted the study.

\section{Conflict of interest}

The authors declare there was no conflict of interest that needed declaration or avoidance.

\section{Nature of study}

This was a B.Sc. Honours in Food Science and Nutrition student project of Karatina University. 
To cite this article: Sewe, D.S. \& Lokuruka, M.N.I. (2020). Coping Strategies to Food Insecurity Employed by Students of Karatina University, Kenya. J. Food Nutr. Sci. Res. 2(1), pages-------. DoI: -----/---.

\section{REFERENCES}

Adamo, KB., Sheel, AW., Onyera V., Waudo, J., Boit, M., and Trendlay, M.S. (2010). Child obesity and fitness levels among Kenyan and Canadian children from rural and urban environments. AKIDS-CAN research alliance study. Int. J. Pediatric Obesity, 6, e225e232.

AOAC. (2005). Official Methods of Analysis of the Association of Official Analytical Chemists international. Maryland, USA.

AOAC. (2017). Protein Determination methods. https://www.mdpi.com/2304-8158/7/1/5/pdf. MDPI journal. Volume 1. 2020-11-25.

Castillo, A. (2007). Journal of biochemistry. https://www.researchgate.net/publication/230090513_Phytate_content_and_its_effect_on cooking quality of beans. Pages 364-367. Accessed on 25-11-2020.

Choukem SP et al. (2018). Overweight and obesity in children aged 3-13 years in Urban Cameroon, A cross-sectional study of the prevalence and association with socio-economic status. BMC Obesity, 4, 1-18.

Crush, J. and Frayne, B. (2010). The Invisible Crisis: Urban Food Security in Southern Africa. Urban Food Security Series 1. Cape Town: African Food Security Urban Network (AFSUN). South Africa.

Daniel, P. (2015). Harvard Health Publishing. https://www.health.harvard.edu/blog/how-muchprotein-do-you-need-every-day201506188096\#: :text=The\%20Recommended\%20Dietary\%20Allowance\%20(RDA,meet\%20y our\%20basic\%20nutritional\%20requirements. Accessed on 19-11-2020.

Devindra, S. (2015). Estimation of glycemic carbohydrates from commonly consumed foods using modified anthrone method.

https://www.researchgate.net/publication/305659058_Estimation_of_glycemic_carbohydrates_fr om_commonly_consumed_foods_using_modified_anthrone_method. Volume 5 Accessed on 1011-2020.

FAO. (2015). Regional Overview of Food Insecurity: Africa: African Food Security Prospects, Brighter than Ever. Accra, Ghana.

Freudenberg, J.S. and Middleton. R.H. (2001). Minimum variance control over a Gaussian communication channel- IEEE Transactions on - ieeexplore.ieee.org.

Government of Kenya. (2008). Household Food Security and Coping Strategies among small scale farmers in Tharaka Central location, Kenya. International Journal of Humanities Social Sciences and Education (IJHSSE)Volume 2 Issue 2.

Hawach Scientific. (2018). The Principle f Soxhlet Extraction.

https://www.hawachextractionthimble.com/the-principle-of-soxhlet-extraction/. Accessed 202011-11. 
Kenya Food Security Steering Group. (2020). http://www.foodsecurityportal.org/kenya/foodsecurity-report-prepared-kenya-agricultural-research-institute. Accessed 08-09-2020.

Kissler, S. (2020). Harvard School of Public Health Journal: The Nutrition Source. https://www.hsph.harvard.edu/nutritionsource/iron/. Accessed on 25-11-2020.

Masutha, M.M. (2011). Investigating the food security experience of financial aid students living in a self-catering residence of Esseen Street and the relationship between their food security status and their financial aid package. BSc. Honours Research Report, Wits University, Johannesburg.

Muhihi et al. (2013). Prevalence and determinants of obesity among primary school children in Dar s Salaam, Tanzania. Archive of Public Health, 26.

Munro, N. (2013). Hunger for Knowledge, Food Insecurity among Students at University of KwaZulu-Natal. Found at:

https://www.researchgate.net/publication/277291353_Hunger_for_knowledge_Food_insecurity_ among_students_at_the_University_of_KwaZulu-Natal. Volume 9. Accessed 2020-09-09. National Academy of Sciences. (2020). Recommended Daily Allowances, $10^{\text {th }}$ edition. https://www.ncbi.nlm.nih.gov/books/NBK234929/\#: :text=Energy\%20allowances\%20range\%2 0from\%202\%2C300,kcal\%2Fday\%20for\%20adult\%20women. Accessed on 11-09-2020.

Rudolph, Michael., Florian Kroll, Evans Muchesa, Anri Manderson, Moira Berry, and Nicolette Richard. (2018). Food Insecurity and Coping Strategies amongst Students at University of Witwatersrand. Journal of Food Security, Vol. 6, No. 1, 20-25.

Scholey A.B, Harper S, Kennedy D. (2001). Cognitive demand and blood glucose. Elsevier Publishers. University of Northhumbria. Volume 2.

Stephen, O. Odebero., Joseph N. Bosire, Anthony K Sang, Fredrick B. J. Ngala and Moses W. Ngware. (2007). Equity in the distribution of HELB loans in Kenya in relation to students' characteristics, Volume 2, Nairobi, Kenya.

Supplemental Nutrition Assistance Program. (SNAP). (2016). Nutrition Assistance. https://www.fns.usda.gov/snap/supplemental-nutrition-assistance-program. Accessed on 2020-09-09.

The Project Crew. (2015). The Taro Yamane Method. https://www.projectclue.com/view-

blog/how-to-determine-a-reliable-sample-size-for-your-research-

work\#: :text=Taro\%20Yamane $\% 20 \% 2 \mathrm{C} \% 20 \mathrm{a} \% 20$ mathematical\%20statistician,which $\% 20$ the $\%$ 20sample\%20was\%20gotten.\&text=n\%3D\%20100. Accessed on 09-09-2020.

World Health Organization. (2008).

https://www.cfs.gov.hk/english/multimedia/multimedia_pub/multimedia_pub_fsf_29_02.html. Accessed on 10-11-2020.

World Health Organization. (2018). Nutrient Requirements and Dietary Guidelines. https://www.who.int/nutrition/publications/nutrient/en/. Accessed on 11-09-2020. 